\title{
Does obturator nerve block always occur in 3-1 block?
}

\author{
Obturator sinir 3-1 blok ile her zaman bloke olur mu? \\ Pakize Kirdemir ${ }^{1}$, Ayhan Comert², Simel Kendir ${ }^{2}$, İbrahim Tekdemir ${ }^{2}$, Alaittin Elhan ${ }^{2}$ \\ ${ }^{1}$ Medical Faculty of Suleyman Demirel University, Department of Anesthesia and Reanimation, Isparta-Turkey \\ ${ }^{2}$ Medical Faculty of Ankara University, Department of Anatomy, Ankara-Turkey
}

\begin{abstract}
Objective: In the femoral "3-in-1 block", obturator nerve block is routinely unsuccessful. Anatomical studies are not available to explain why blockade of obturator nerve or lumbar plexus does not occur. The aim of this study was to examine the effectiveness of femoral "3-in-1 block" obturator nerve block on a cadaver model.
\end{abstract}

Materials and methods: Totally, 12 mature adult human cadavers were selected. Methylene blue dye $(30 \mathrm{ml})$ was injected under the fascia iliaca in eight cadavers and into the femoral nerve sheath in four cadavers. Careful bilateral dissections were performed following dye injections.

Results: It was seen that the dye did not spread to the medial part of the psoas major muscle and the obturator nerve was not stained with the dye in eight cadavers in whom dye was injected laterally into the femoral sheat. In four cadavers in whom dye was injected into the femoral nerve sheat, metylene blue spread through fascial layers in the plane under the psoas muscle and stained the obturator nerve just before emerging medially from the fascia psoas. At this point, the obturator nerve pierced the psoas fascia and extended extrafascially in the medial and deep borders of the psoas muscle. In this area, the upper section of the obturator nerve was found also to be stained with the dye.

Conclusion: We concluded that the cause of an unsuccessful obturator nerve block might be the fascial anatomy of this region. The lateral cutaneous femoral nerve and the femoral nerve easily can be blocked in the fascia iliaca compartment, but the obturator nerve block fails because of its being extrafascial in this region. J Clin Exp Invest 2011;2(2):149-51

Key words: Obturator nerve, femoral nerve, nerve sheath, anesthetic techniques.

\section{INTRODUCTION}

Block 3 in 1 was described by Winnie in $1973 .^{1}$ This technique is supposed to block of the femoral, femoral cutaneous, and obturator nerves by a single

\section{ÖZET}

Amaç: Femoral "3-1 blok" uygulamalarında obturator sinir bloğu genellikle başarısız olmaktadır. Obturator sinir veya lomber pleksus bloğunun niçin oluşmadığını açıklayıcı yeterli sayıda anatomi çalışması bulunmamaktadır. Bu çalışmanın amacı, femoral 3-1 obturator sinir bloku etkinliğini bir kadavra modeli üzerinde incelemektir.

Gereç ve yöntem: Toplam 12 erişkin insan kadavrası seçildi. Sekiz kadavraya $30 \mathrm{ml}$ metilen mavisi iliak fasiya altına ve dört kadavraya da femoral sinir kılıfı içerisine enjekte edildi. Daha sonra dikkatli bilateral disseksiyon yapıldı.

Bulgular: Femoral kılıfın lateraline metilen mavisi enjekte edilen sekiz kadavrada metilen mavisinin psoas major kasın medialine yayılmadığı ve obturator sinire ulaşmadığı görüldü. Femoral sinir kılıfı içine metilen mavisi enjekte edilen dört kadavrada ise metilen mavisinin psoas kasının altından fasialar arasında yayıldığı ve obturator siniri boyadığı görüldü. Bu noktada obturator sinir psoas fasiyasını delerek ekstrafasiyal olarak psoas kasının orta ve derin kenarında ilerlemektedir. Bu alanda obturator sinirin üst bölümü de boyandı.

Sonuç: Sonuç olarak başarısız obturator sinir bloğunun buradaki fasiya anatomisine bağlı olarak gelişiyor olabilir. Femoral ve lateral femoral kutanöz sinir subfasiyaldir ve bu iki sinir fasiya iliaka alanında kolaylıkla bloke olmaktadır, ancak obturator sinir bu bölgede ekstrafasiyal alanda bulunduğu için bloke olmamaktadır. Klin Deney Ar Derg 2011;2(2):149-51

Anahtar kelimeler: Obturator sinir, femoral sinir, sinir kıIıfı, anestezik teknikler.

injection. In recent years, this technique has been used as an effective alternative for arthroscopic surgery anesthesia and any superficial surgery such as skin harvesting or a biopsy of the quadriceps muscle

Yazışma Adresi /Correspondence: Doç. Dr. Pakize Kırdemir, Medical Faculty of Suleyman Demirel University, Department of Anesthesia and Reanimation, Isparta-Turkey, Email: pkirdemir@hotmail.com Geliş Tarihi / Received: 29.07.2010, Kabul Tarihi / Accepted: 09.04.2011

Copyright (C) Klinik ve Deneysel Araştırmalar Dergisi 2011, Her hakkı saklıdır / All rights reserved 
can be done. Winnie, hypothesized that "If a volume of $20 \mathrm{ml}$ or more is utilized, anesthesia of all three nerves is virtually assured". ${ }^{1}$ Ritter indicates that "3-in-1 block" probably does not block the lumbar plexus or the obturator nerve. ${ }^{2}$ Lonsdale $^{3}$ has confirmed Winnie's anatomical hypothesis. ${ }^{3}$

Obturator nerve block is routinely unsuccessful in the femoral "3-in-1 block". Anatomical studies are not available to explain why blockade of obturator nerve or lumbar plexus does not occur. Therefore, in this study, we performed an anatomical cadaveric study to explain the anatomical basis of why obturator nerve block does not occur.

\section{MATERIALS AND METHODS}

Totally, 12 mature adult human cadavers were selected for the study. Cadavers with a history or evidence of surgery in the lower abdomen, pelvis and inguinal regions were excluded. Age, height, and weight were not included as the criteria for selection in all of the cadavers. A $15 \mathrm{~cm}, 22$-gauge catheter was inserted $2 \mathrm{~cm}$ distal to the inguinal ligament and $1 \mathrm{~cm}$ lateral to the femoral artery at a $30^{\circ}$ angle cephalad and underneath the iliac fascia and fascia lata. Thirty $\mathrm{ml}$ of methylene blue dye was slowly injected via the catheter. Without disturbing the adjacent anatomic structures bilateral dissection was performed.

The fascia of the iliacus muscle was opened and the femoral, lateral femoral cutaneus and obturator nerves were dissected. Sections in horizontal planes were made and examined in Department of Anatomy with an aid of surgical microscope. In four cadavers, inguinal section of the femoral nerve was dissected and a catheter was inserted at a $5^{\circ}$ angle and $1 \mathrm{~cm}$ thrust into the sheath and $30 \mathrm{ml}$ of dye was injected. The abdominal cavity was then opened and we observed if the nerves were stained with dye.

\section{RESULTS}

In eight cadavers where the dye was injected laterally into the femoral sheath, the dye did not spread to the medial part of the psoas major muscle and the obturator nerve was not stained with the dye. Two other nerves were stained with dye in all cadavers. In four cadavers, a part of the femoral sheath under the inguinal ligament was found to be very thick and after careful dissection of this region, it was ob- served to be comprised of the part above the inguinal ligament blending with the iliac and psoas fascia. The sections in horizontal plane, examined with microscopic dissection, support these findings.

Based on our observations, this sheath cannot transport the local anesthetic to the lumbar plexus because this sheath covering the femoral nerve is not thick or strong enough and has a cribriform structure. Cadavers in whom dye was injected in the femoral sheath, the lateral femoral cutaneous nerve and the femoral nerve were stained with dye; during the dissection, we observed that the part under the psaos was not stained with the dye because the mass of the psoas muscle was pressured where the cross section of this nerve was seen to be flat and somewhat wide. Dye was spread through the fascial layers in the plane under the psoas muscle and the obturator nerve was found to be stained with dye just before emerging medially from the fascia psoas and at that point, the obturator nerve pierced the psoas fascia and extended extrafascially in the medial and deep border of the psoas muscle and the upper section of the obturator nerve was also seen to be stained with dye.

\section{DISCUSSION}

Major potential benefits of peripheral nerve block techniques may include postoperative analgesia, less physiologic derangements, more rapid postoperative recovery, avoidance of airway instrumentation, and a reduced incidence of potential complications associated with general anesthesia (nausea/ vomiting, aspiration, inability to ventilate/intubate, and malignant hyperthermia). Cauhepe et al. ${ }^{4}$ have reported that the external diffusion of the liquid in front of the iliacus muscle never reached the internal side of the psoas major muscle, and thus the obturator nerve, in their anatomical study. ${ }^{4}$

The anatomy literature fails to describe a fascial "sheath" around the femoral nerve capable of acting as a liquid to conduit to the lumbar plexus. ${ }^{5-8}$ In a study, femoral and lateral femoral cutaneous nerves have been stained following femoral intraneural injection, but the obturator nerve has not been stained. Our findings support that the femoral nerve does not have a fascial sheath but following our injection, dye was spread posteriorly and cephalad to a point above where the obturator nerve pierces the illiacus fascia. It has been stated that, this technique anesthe- 
sizes only two nerves, and hence should be called a "2-in-1 block" and others reported that lateral femoral cutaneous nerve is blocked almost every time, but only four patients had abductor paralysis following the 3-in-1 block. ${ }^{9,10}$ Rosenblatt's report presented X-ray evidence that a catheter can be placed in the sheath surrounding the femoral nerve. ${ }^{11}$ Our findings support that liquid cannot spread medially to reach the obturator nerve because this nerve is extrafascial on the medial side of the psoas. Having the anesthetic reach the obturator nerve is possible because of the relation of the femoral nerve sheath with the fascial structure of this region.

For obturator nerve blockade, the anesthetic should be injected in the femoral nerve sheath and we believe that our method would increase the success of this nerve block. In a study, it has been concluded that the femoral 3-in-1 block does not block the parent trunk of the obturator nerve, where the obturator nerve block was successful in only one of 26 patients. ${ }^{12}$ Dupré indicates that " 3 -in-1" block is supported by the idea of diffusion within a space that is located after going through two fascial layers. ${ }^{13}$ However, when we used this space in eight cadavers, we spared the obturator nerve completely because of the anatomic structure of the psoas muscle cleavage and extrafascial obturator nerve.

As a conclusion, cause of an unsuccessful obturator nerve block may not be related to the experience of anesthesiologist but it may be depends on the fascial anatomy of this region. The femoral nerve is covered with a "sheath" which is thicker around the inguinal ligament. The lateral cutaneous femoral nerve and the femoral nerve are subfascial and these two nerves easily can be blocked in the fascia iliaca compartment, but the obturator nerve block fails because of its being extrafascial in this region.

\section{REFERENCES}

1. Winnie AP, Ramamurthy S, Durrani Z. The inguinal paravascular technic of lumbar plexus anesthesia: the "3-in-1 block”. Anesth Analg 1973;52(8):989-96.

2. Ritter JW. Femoral nerve "sheath" for inguinal paravascular lumbar plexus block is not found in human cadavers. J Clin Anesth 1995;7(4):470-3.

3. Lonsdale M. 3-in-1block: confimation of Winnie's anatomical hypothesis. Anesth Analg 1988;67(5):601-2.

4. Cauhepe C, et al. The "3-in-1" block: myth or reality? Ann Fr Anesth Réanim 1989;8(3):376-8.

5. Gardner E, Bunge R. Gross anatomy of the perpheral nervous system. In: Dyck P, Thomas P (eds): Peripheral Neuropathy, 3rd ed. Philadelphia: W.B. Saunders Co., 1993:21-2.

6. Thomas $\mathrm{P}$, et al. Microscopic anatomy of the peripheral nervous system. In: Dyck P, Thomas P (eds): Peripheral Neuropthy, 3rd ed. Philadelphia: W.B. Saunders Co., 1993:21.

7. Pick TP, Howden R. Muscles and fasciae of the lower extremity. In: Pick TP, Howden R, eds. Gray's Anatomy: The Classic Collector's Edition. New York, Crown, 1977:416.

8. Williams PL, Warick R, Dyson M, Bannister LH. Gray's anatomy. 37th ed. London: Churchill Livingstone, 1989:371-3.

9. Spillane WF. 3-in-1 blocks and continuous 3-in-1 blocks. Reg Anesth 1992;17(2):175-6.

10. Parkinson SK, Mueller JB, Little WL, et al. Extend of blokade with various approaches to the lumbar plexus. Anesth Analg 1989;68(4):243-8.

11. Rosenblatt RM. Continuous femoral anesthesia for lower extremiy surgery. Anesth Analg 1980;59(6):631-2.

12. Lang SA, Yip RW, et al. The femoral block revisited. J Clin Anesth 1993;5(4):292-6.

13. Dupré LJ. "Three-in-one" block or femoral nerve block. How and when to do it? Ann Fr Anesth Réanim 1996;15(8):1099106. 